\title{
1. John Locke and the Three Pillars of Liberty
}

\section{ANCIENTS VERSUS MODERNS}

It is customary to present histories in chronological order. We do not object to chronological order. In addition, some scholars have understood and presented the history of political thought per se as a debate between ancients (primarily Plato and Aristotle) and moderns. In itself this can be very insightful. It has, however, serious limitations. To begin with, it largely ignores or downplays the importance of economics, especially in the modern period. More to the point, it tends to privilege the views of the ancients, sometimes to the point of the distortion of the views of the moderns. We think that while modern thinkers may be illuminated by contrast with classical thinkers, we also think that modern thinkers are better understood in terms of their engagement with each other. This is why we begin the conversation with Locke rather than Aristotle.

As a general point of departure, we can contrast Aristotle's world view with the Newtonian world view. Aristotle's intellectual model was teleological biology. This translated into the belief that every entity had a purpose (telos) and this is what it meant to say it had a nature; the belief that the purpose of each entity fit within a larger net of purposes terminating in one hierarchical overall purpose; that the natural state of each object (Aristotle's physics) was to be at rest and that motion or original motion had to be explained; and that time was to be understood as an endlessly repeating cycle, which is why history is either unimportant or cyclical, and most certainly not evolutionary; and the belief that when applied to human beings the preeminent function was contemplation and serving a larger social purpose. The Newtonian world view was based on modern physics, wherein motion, not rest, was the natural state, and where the ultimate units were individual objects (later atoms) in endless motion without a telos, interacting/colliding with others. When this world view is extended to human beings, it came to mean that action (work), not contemplation, was fundamental, that humans are both a product of their natural drives along with the history and evolution of 
their previous interactions/collisions, and that in the absence of a larger social purpose, the challenge was to manage/minimize conflict.

John Locke (1632-1704) put the economic issue at the center of politics; taking economics out of the household and into the forefront of politics. The purpose of politics, says Locke, is the preservation and regulation of private property. The major consequences of this view are (1) a restructuring of the hierarchy of values, (2) economics becomes the purpose of politics, (3) the disappearance of public political virtue as the primary human objective and character building as the central political objective, (4) the substitution of labor for land as the central concept in economic thought, and with that (5) a reconsideration of the distinction between the 'deserving' and 'undeserving' rich. Aristotle would argue that the public good is greater than the sum of its parts. Not so Locke. Is there a public good or is it somehow a by-product? Answering this question helps us to understand the ideas that emerged over the next 300 years following Locke. According to Locke, we do not see the true nature of human beings in civil society. Human beings need to be 'unmasked' because, unlike Aristotle, Locke does not believe that human nature is revealed in a fully developed social condition (telos) but in its primitive condition (analogue to Newtonian laws of motion). We discover who or what human beings are by contemplating human beings in a natural/ primitive state. The modern rejection of Aristotle's organic conception of the world and its replacement by Newtonian physics requires a derivative intellectual reconceptualization of the social world. For example, Aristotle thought that usury was morally wrong, whereas Locke brought the concept of money into the marketplace. Thus individual liberty and materialistic concerns came to the forefront of life.

\section{LOCKEAN LIBERTY NARRATIVE}

The narrative can be summarized abstractly in terms of the following diagram:

$$
T P \rightarrow M E \rightarrow L G \rightarrow R L \rightarrow C P A \rightarrow T P
$$

TP stands for the technological project.

ME stands for the market economy.

LG stands for limited government (restraining government on behalf of individual liberty).

RL stands for the rule of law.

CPA stands for the culture of personal autonomy. 
The ancients believed that there was an external, objective, and normative order in nature. This meant two things: human beings were obliged to use reason to discover that order and then to conform their behavior to it. The moderns will argue that order is an internal human construct and that we are obliged to transform the world to conform to that internally generated vision of order. This is the philosophical revolution known as the 'technological project'. The Lockean narrative is the assertion of the claims that the technological project, that is, the transformation of the physical world of nature for human convenience, functions best in a free market economy which, in turn, requires a limited government subject to the rule of law, and all of the foregoing operate best within a culture that promotes personal autonomy. Finally, the technological project is itself an expression of personal autonomy. Each of these concepts was articulated prior to Locke. So, for example, Descartes in the Discourse on Method (Descartes 1637) advocated our becoming "masters and possessors of nature." What is significant about John Locke was that he was among the first, if not the first, to articulate and endorse a coherent version of the entire narrative.

Locke was educated as a physician at Oxford where he also met Anthony Ashley Cooper, 1st Earl of Shaftesbury, subsequently becoming part of his retinue. Since Shaftesbury was a founder of the Whig movement (advocating parliamentary limits on royal power), Locke was drawn into politics. Locke was interested not only in political liberty but economic liberty and religious liberty as well.

At Ashley's urging, he prepared a paper in 1668 entitled "Some of the Consequences that are likely to follow upon Lessening of Interest to Four Percent" (Ashley 1692). This paper was a response to English mercantilists, for whom prosperity was a zero-sum affair, and who attributed the superior economic prosperity of their perceived rivals, the Dutch, to Holland's low rate of interest. The mercantilist solution was to urge the English government to reduce the rate of interest until it was lower than Holland's. Locke countered that England's national wealth did not thereby increase because a lower interest rate redistributed wealth from the lender to the borrower. Locke also held that the "value of money" was determined by the plenitude or scarcity of money. This implied that the purchasing power of money fell with the amount of money in circulation, where it would undercut savings and credit, thereby making the economy worse off. National wealth was the product of thrift as well as labor. Instead, Locke advocated the "natural" or the market rate as determined by the supply and demand for money at a given time. Locke later published this argument in Some Considerations of the Consequences of the Lowering of Interest and Raising the Value of Money 
(Locke 1692). In the latter work he expanded his comments to include a critique of debasing coinage, warning that debasement is both illusory and inflationary. Ironically, the proper role of the government is to enforce legal contracts not to itself renege on the promise to ensure sound money.

\section{TECHNOLOGICAL PROJECT}

Locke's study of medicine reflected the seventeenth century emphasis upon health, which in turn, reflected two things: a specifically Protestant cosmology and what we have identified as the Technological Project! The cosmological role of God was summarized by R.G. Collingwood in his The Idea of Nature (Collingwood 1945). Renaissance science took its idea of God from the Bible. God is conceived of as a transcendent Being who created the world with human beings in his own image, and that created world is both knowable and benevolently disposed to human interests. During the Middle Ages, the Chinese were more advanced than the West in scientific matters, but the scientific revolution occurred in the West and not in China. In Science and Civilization in China (Needham [1954] 1984) Joseph Needham's explanation for this is that the Chinese lacked "the conception of a divine celestial lawgiver imposing ordinances on non-human Nature." To be sure, there was order in Nature for the Chinese, but "it was not an order ordained by a rational personal being, and hence there was no conviction that rational personal beings would be able to spell out in their lesser earthly languages the divine code of laws which he had decreed aforetime" (Needham [1954] 1984, p. 581). What the Chinese lacked was the Christian God. The Technological Project gave a new meaning to life. Instead of this world being a temporary residence, God commanded us to develop it. Martin Luther stressed that worldly work is a duty benefiting both the individual and society. The Catholic notion of good works was transformed by Calvin into an obligation to work diligently as a sign of grace.

In England during the sixteenth and seventeenth centuries, Protestants who followed Calvin became known as Puritans. Locke was a Puritan. The Puritans venerated work. God had intended us to work, and therefore had designed us so as to take pleasure in those things that required work. Good health is required for an active and useful life. Even knowledge, it was thought, originated in work with a practical import as opposed to contemplation. As an example of this view, there was in seventeenthcentury England a vigorous expansion in medical studies. John Locke was part of that expansion. 
God-inspired labor created something that was not already there, namely, new resources. These new resources constitute the theoretical defense of private property. This property, therefore, is a natural right given by God and does not require legitimation by government. Precisely because new property can be created there is no theoretical limit on accumulation. The only limitation is that we do not prevent others from a like accumulation. Unlimited accumulation does not operate in a zerosum universe but in a theologically inspired conception of creating new wealth through labor. Locke also presumed that God created a universe in which our personal self-interest does not ultimately conflict with the interests of others. In fact:

when his own preservation comes not in competition, [he] ought ... as much as he can ... preserve the rest of Mankind, and may not unless it be to do Justice on an Offender, take away, or impair the life, or what tends to the Preservation of the Life, the Liberty, Health, Limb or Goods of another. (Locke 1689, Second Treatise, \#6)

Note the qualification, "when his own preservation comes not in competition," for it excludes attributing to Locke any form of collectivism, that is, sacrificing the individual without his/her consent to a greater social good. More importantly, we have an obligation to improve the material circumstances of others - but not through redistribution! Rather, the improvement of others is the result of our self-improvement.

In a potentially infinitely expanding economy, inequality of property is not a problem. A day laborer in England is better off than the richest king in Africa (Locke 1689, Second Treatise, \#40-41). What becomes a social problem is the existence of those who choose to accumulate things without working (for example, theft, begging, and so on). Although Locke's argument was inspired by theological beliefs, once the Technological Project is recognized and articulated the entire argument can be held without a specific theological commitment. Later thinkers who prefer social science to theology will maintain that animals have a natural sense of territoriality. Critics of the Lockean narrative who also prefer social science will respond that the narrative leads to "social Darwinism." Other critics who prefer physical science will worry that humanity will eventually run out of resources. Defenders of the Lockean narrative will respond that human imagination is the greatest resource, that it will always come up with an alternative precisely because the price system in the market will incentivize them to do so. And so it goes. Nevertheless, there is at the heart of Locke's narrative a spiritual quest - what will evolve in the thought of others as the spiritual quest of modernity, the improvement of the human condition. 
Labor does not create value except in a theological-metaphorical sense; what labor creates is a new resource or new property, even new kinds of property. The value of that property in economic terms is given a price, but the natural price is determined by supply and demand. Labor increases the supply of goods and services; the price of such is determined by demand as well as supply. Furthermore, the TP leads to the creation of "durable" goods. Human beings can now exchange their perishable goods for goods that would last longer. The introduction of money is the culmination of this process. This is consistent with the pursuit of happiness, contrary to what the Aristotelian tradition teaches.

There are numerous appeals to Biblical texts in Locke's discussion dealing with the origin and defense of private property. How important is the religious component of Locke's argument? If we were to take away the religious dimension would Locke's argument be fundamentally altered? The answer is both 'no' and 'yes.' An important part of Locke's project, as we shall see, is religious liberty. We remind the reader of the importance of the three pillars of liberty.

There is a strong moral tone - even a God inspired biblical inclination toward "stewardship" and such higher ends as the "common good" - to Locke's defense of private property. This is particularly evident in his critique of wasting and spoiling as unjust as well as his defense of individual self-reliance, public stewardship; even his 'rights' doctrine was derived from God.

The best thing God did was to punish Adam and make him work for himself. Was this punishment actually a gift? The key to human life is self-improvement. If human beings work and acquire things, they'll be more willing to work and become self-reliant. They will learn how to govern themselves economically. And, who knows, they may learn to govern themselves in matters of politics and religion. Locke did not see labor as a punishment but as a reward. The interesting thing is that the American Founding Fathers did see Locke as a Christian. They saw a difference between Hobbes and Locke. Some try to read Locke out of the American founding. In doing so, they devalue the importance of the market, and the link between the trinity of liberty in economic, political, and religious matters.

Locke understood 'nature' from a Newtonian point of view. 'Nature' was not revealed as the terminus of an Aristotelian teleological process but as the hypothetical primitive condition (first law of motion) which is itself revealed in, and modified by, the interaction among things (second and third laws), all of which is discovered by observation of the world not the reading of texts. Humanity discovers itself through work - by interaction with the physical world. As in Newton, these basic laws of 
nature are ordained by God. My 'rights' are 'natural' in that they are ordained by God and revealed through the interaction with and transformation of the physical world. God has granted me the 'right' to life, to 'liberty' (freedom to pursue my natural drives unencumbered by others, that is, monarchs and aristocrats) and especially the right to pursue happiness through work.

\section{MARKET ECONOMY: ECONOMIC LIBERTY}

Locke's initial intuitive grasp of economics reflected his training as a physician. He was sympathetic to the view that the body healed itself and that the role of the physician was to subtend this natural process. This medical bias, so to speak, was shared with two earlier thinkers, Rene Descartes and Francis Bacon. In Bacon's New Atlantis (Bacon 1627), Solomon's House was focused on gaining control over the environment, including medical advice for prolonging life. Descartes maintained that "The preservation of health has always been the principle end of my studies" (Descartes 1991, p. 275).

With regard to the domestic economy, Locke advocated a relatively free market. Wealth is measured by gold and silver, for these command all the conveniences of life. In a country not furnished with mines, there are but two ways of growing rich, either conquest or commerce. For Locke, commerce is the only way. Gold and silver, as opposed to paper money, are the appropriate currency for international transactions because they are universally recognized by all of humanity. The value of paper money is only valid under the government which issues it.

Locke later served as Secretary of the Board of Trade and Plantations and Secretary to the Lords Proprietor of Carolina, and this seems to have influenced his ideas on international trade and economics. With regard to the international economy, Locke urged England to seek a favorable balance of trade, lest it fall behind other countries and suffer a loss in its trade. Further, he was, on occasion, prepared to recommend tariffs. Locke was certainly aware of the balance of power at that time, but he also worked with the assumption that the potential for war is an unfortunate feature of the world in which he lived, just as he thought the existence of the universal moral truths in the state of nature will inevitably be violated by a few. It will be up to Adam Smith and Immanuel Kant, in later stages of the narrative, to argue for international free market and perpetual peace, but nothing in Locke's narrative precludes that.

According to Locke, if you labor over something, that something becomes your private property. At this point the argument for private 
property is moral. When we shift from a barter economy to a monetary economy there is a marked difference to the whole argument for private property. With the introduction of money, we have shifted from a way of life which is primarily nomadic and agrarian to an entrepreneurial one where investment and acquisition take place. We're on the road to free enterprise and an autonomous existence. Here we see the introduction of a second factor in production, namely, capital. Labor could not be as productive without the capital. In a barter economy, labor is the only factor. With capital comes interest. No longer was usury illegal. In arguing against the government setting the rate of interest, Locke is one of the first to make a case for the market price against a church or government determined price.

Locke is not defending the property of the rich. He talks about God favoring the rational and industrious. He is arguing that the rational and industrious are the many, ready to improve their plight. If just given a chance, they will take care of themselves.

God gives the world to human beings in common. But he could never have intended for the world to be divided equally. He rewards those who help themselves rightly. The origin of private property is a mix of God's gift and human labor. Private property is not deemed to be theft. What is due to God and what is due to human? The value of $\mathrm{X}$ is 99 percent due to human labor and 1 percent to the land. God gave the land. Ergo what God gave is useless - unless there are humans to use it. We cannot understand Locke on private property unless we understand his stance on private religion. It is part of God's design for human beings that they become self-sufficient. This stems from Protestantism, and this never would come from Catholicism.

Locke argued that the market should decide the price. Making money off of money should be done openly and if the market supports gouged prices then so be it! When the market decides, it becomes legitimate; consequently, open markets are legitimate! Prices were decided by church fathers or philosophers for too long. Locke tries to make the case for the market price. In the 1570s, before Locke, an Ethics panel decided to shift from saying usury is always bad to sometimes being good. Locke had to demonstrate that making money from money is natural.

While serving as Secretary for the Board of the Lord Proprietors of Carolina, Locke allegedly helped draft the Fundamental Constitutions of 1669 which sanctioned slavery. In addition Locke invested (through his patron Shaftesbury) in the African slave trade, an institution that was systemic to the overall economy of Britain. A number of interminable and speculative scholarly debates have raged around whether Locke was an advocate of slavery, and so on. On the one hand this is relevant 
because Locke is an advocate of universal individual freedom. Whether Locke condoned Negro slavery or was acting prudentially in an imperfect world or whether he was a hypocrite is not something that scholars can definitively establish.

What we know, following Chapter 4 of the Second Treatise in which Locke discusses slavery, is that one is not free to choose to become a slave. We want to suggest that this is the first coherent case against slavery ever, and this case is relevant to the future of liberty.

Moreover, none of these possibilities vitiates the narrative from $\mathrm{TP} \rightarrow \mathrm{ME} \rightarrow \mathrm{LG} \rightarrow \mathrm{RL} \rightarrow \mathrm{CPA}$. Locke advocated each and every one of these elements of the logic of modernity and clearly saw the connection between and among the elements. Nor was it necessary for Locke to foresee all of the later implications and permutations of the narrative. The real importance of the scholarly debate about slavery, although it looks like a purely scholarly debate, is that it is a reflection of what will be the Rousseauean (scholarly) critique of the Locke narrative. Part of that critique, as we shall see, is that the Lockean contract, allegedly, was an imposition of the strong upon the weak; in short, an excuse for exploitation. Somehow, Locke's alleged hypocrisy and covert support of slavery is supposed to show us the true motive behind the Lockean narrative or all those who are attracted by the narrative. Critics have also added to his list of shortcomings the claim that the argument against unenclosed property is a covert argument that permits dispossessing natives in the New World. This issue is still with us in the form of eminent domain.

\section{LIMITED GOVERNMENT: POLITICAL LIBERTY}

Locke is most famous for his advocacy of limited government. Around 1689 Locke published anonymously the Two Treatises of Government. The First Treatise had critiqued Robert Filmer's argument that monarchy was a form of Biblically justified patriarchy. Locke argued that God had given the Earth to mankind in common and not to a patriarch. The Second Treatise is, among other things, an account of how land, originally given in common by God, leads to inviolable private property, and thus to limited government.

Three important elements of the logic of modernity are present in the Second Treatise: the technological project, the market economy, and limited government. The technological project is explicitly expressed in the view that human effort is what gives entities in the world their meaning and value in a philosophical and religious sense. 
God, who has given the world to men in common, has also given them reason to make use of it to the best advantage of life, and convenience ... it cannot be supposed He meant it should always remain common and uncultivated. He gave it to the use of the Industrious and Rational ... not to the Fancy or Covetousness of the Quarrelsome and Contentious ... for it is labor indeed that puts the difference of value on every thing ... of the products of the earth useful to the life of man nine tenths are the effects of labor. (Locke 1689, Second Treatise, Chapter 5, The Right of Private Property, sections 26, 27, 34, and 40)

Locke's critique of Patriarchy is more than just an attack on divine right monarchy or a rationalization for a revolution. Patriarchy was used to justify government control of the economy, something incompatible with human flourishing as understood by the Puritans. The royal prerogative also meant taxation without consent, which is wholly incompatible with the Puritan understanding of private property. Locke was not an advocate of the redistribution of wealth. Moreover, Patriarchy reflects the view that society was a collective whole within which individuals subordinated their private aims for the public good, what Hayek will call a teleocracy and what Oakeshott will call an enterprise association. This is precisely what Catholicism advocated in Locke's time, it is what France under the Bourbons represented, and it was what a Catholic King of England would adhere to. Locke rejected and revolted against this collectivist understanding of society.

It is fashionable nowadays to ignore or dismiss Locke's use of Protestant theology to express his vision or narrative. We note only in passing that a case can be made that there were no other available conceptual frameworks in Locke's time, philosophical or otherwise, for articulating Locke's insights. This is part of what is intriguing in the later evolution of the Locke narrative.

The technological project requires a market economy for its full expression. A free market economy is a system for the exchange of goods and services wherein there is no central allocation of such goods and services. The goods and services are privately owned (that is, private property). It involves competition because innovation cannot, by definition, be planned. To the extent that property is privately owned and not centrally controlled, and to the extent that a free market economy is competitive, there is a greater possibility for innovation. Three things, in Locke's mind, legitimate private property: (1) it is more productive (this was confirmed in Locke's time by the land-enclosure acts); (2) it exemplifies a personal relationship with God; and (3) it acknowledges the spirituality of work. Adam Smith will elaborate the first element (efficiency) by reference to specialization, and he will elaborate the second 
element in the metaphor of the "hidden hand" - a quasi-theological guarantee that the self-interest of each individual is compatible with the self-interest of everyone else. The spirituality of work will be preserved in a secular fashion, as we shall see, by Hegel.

For Locke the "great and chief end therefore, of Mens uniting into Commonwealths, and putting themselves under Government, is the preservation of their property" (Locke 1689, Second Treatise, paragraph 124). The formation of government requires majority consent (as apparently does revolution), but the actual form of government need not be a democracy. In fact, majoritarian consent to a policy does not legitimate that policy if it violates the law of nature. This is fundamentally different from Rousseau's view.

Locke advocates a property qualification for political participation as a safeguard against democratic (mob) rule. Again, this is a signal to advocates of the Rousseau narrative that the Lockean narrative is a way for the few strong to subordinate the many weak. As made clear later by Madison in the Tenth Federalist Paper, democracy is a negative blocking device - not a positive creation device. Moreover, as we shall see, Locke's argument stripped of theology and advocating that government is legitimated only by consent will be reiterated by Hume, Madison, and J.S. Mill.

\section{RULE OF LAW: ECONOMIC, POLITICAL, AND RELIGIOUS LIBERTY INTERTWINED}

We are not concerned here with Locke's controversial discussion of the relationship between natural law and natural right or the relation of natural law to civil law. However important and interesting these topics are, they do not contribute to our understanding of the narrative. The rule of law attained extraordinary prominence in seventeenth century England. This is reflected in Locke's Second Treatise.

The end of law is, not to abolish or restrain, but to preserve and enlarge freedom ... where there is no law there is no freedom. For liberty is to be free from restraint and violence from others ... and is not, as we are told, a liberty for every man to do as he lists ... a liberty to dispose, and order as he lists, his person, actions, possessions, and his whole property, within the allowance of those laws under which he is, and therein not to be subject of the arbitrary will of another, but freely follow his own. (Locke 1689, Second Treatise, VI, paragraph 57) 
The purpose of law is to minimize conflict, not to achieve a positive end. As we shall see in the later development of the narrative, it is what Oakeshott will call the 'rule of law' in a civil association. This is achieved by appeal to past practice (that is, the common law) and not to abstract first principles. Past practice is substantiated by historical experience, and that is why Locke and others appeal to their understanding of an historical tradition that stretches back to time immemorial (and the state of nature) in which the struggle of the Commons against prerogative is the major theme.

As an early advocate of the separation of powers, his main focus is on limiting "him that has the executive power" (Locke 1689, Second Treatise, paragraph 159). Although conceding the necessity for the executive to exercise prerogative power or discretion (Locke 1689, Second Treatise, paragraph 164, "Prerogative can be nothing, but the Peoples permitting their Rulers, to do several things of their own free choice, where the Law was silent, and sometimes against the direct Letter of the Law, for the public good; and their acquiescing in it when so done"), Locke reminded executives that such acquiescence could turn into revolution. The only thing worse than revolution is oppression; and revolution is a historically grounded practice, not a theory.

In describing law, Locke stipulated the following characteristics: (1) law cannot be arbitrary (Locke 1689, Second Treatise, \#135); laws must be (2) general, (3) public, (4) everyone including the ones who make laws must be subject to law (Locke 1689, Second Treatise, \#137), and (5) no legitimate act of government can appropriate property through taxation without consent.

\section{CULTURE OF PERSONAL AUTONOMY}

Following Hobbes, Locke accepts the ontological priority of the individual will. Locke's Essay Concerning Human Understanding (1690) is known largely for its epistemological doctrines, but it is at the same time an early expression of what Oakeshott will later identify as the modern Renaissance conception of the self and personal identity by reference to each individual's consciousness. In the Vindication of the Reasonableness of Christianity (1695), Locke went so far as to cite Genesis, specifically the biblical doctrine of Imago Dei specifically as a basis for individual freedom and equality, including equality of the sexes. By proclaiming political individualism Locke repudiated 500 years of hierarchical political communitarianism. 
A Letter Concerning Toleration (1689) is not only a classic statement of religious toleration or liberty but an expression of Locke's emphasis on the importance of individualism. Inherent in Christianity is the recognition that salvation is only attainable by sincere inner personal belief. Hence individuals must be free to come to God each in his/her own way. Moral sovereignty over one's personal core beliefs and practices is constitutive of being an individual. This position will be subsequently elaborated in a secular manner by J.S. Mill when he writes On Liberty (Mill 1859). The great threat to social disorder is not individual dissenters, but those who insist that society must be a collective (an enterprise association in Oakeshott's terminology), for the latter masks personal ambition under the guise of ideology. This will be the 'Lockean' refrain against those who maintain that civil strife requires subordination to a collectivity. It is modernity's answer to the ancients and modern collectivists.

Locke does recognize the existence of the socially dysfunctional, identifying them both as those who refuse to support themselves through work and in the expression the "Fancy or Covetousness of the Quarrelsome and Contentious." In contrast with Rousseau, Locke recognizes the existence of the dysfunctional as reflecting a personal moral shortcoming and not a systemic failing. Locke thus introduces a continuing issue in the debate between the Locke narrative and the Rousseau narrative. For Locke and his followers, the dysfunctional fail to grasp or choose to disregard the liberating effects of the technological project, just as they failed in the state of nature to accept the God-guaranteed inner moral law. In Kant, the failure will be explained as the substitution of the heteronomy of the will as opposed to autonomy - an autonomous person never exploits others for that is to define oneself by one's victims. For Hegel, the recognition of our autonomy requires that we promote it in others. In Oakeshott, the dysfunctional will be identified as the antiindividuals who still cling to a pre-modern collective identity. In the Lockean narrative, the polity is defined by the successful; in the Rousseau narrative the polity is defined by the alienated.

Locke provides a quasi-historical account of the evolution from agriculture to commerce with its accompanying evolution of human personal sensibility. This evolutionary account will be extended more explicitly during the Scottish Enlightenment by Smith and further developed by Kant and Hegel.

Advocates of holism or collectivity insist that conflict can be avoided and fulfillment obtained only by participation in a substantive collective telos - this is a view shared by ultra-conservatives on the right and radicals on the extreme left. The 'Lockean' response is twofold: 
(1) minimizing or eliminating conflict is best obtained by agreement on procedure (for example, toleration) not on substance; in fact, the latter fuels conflict; (2) happiness is what we pursue not necessarily what we obtain in this life; substantive fulfillment is something for the afterlife. Substantive views, whether religious or philosophical, are private.

There is a marked tendency for advocates of the Lockean Liberty Narrative to present themselves in a triumphalist fashion. Francis Fukuyama's The End of History (Fukuyama 1992) is among the latest such expressions. This is not to deny the existence of problems, tensions, and misunderstandings, but it does reflect a sense that somehow they speak for the inevitable and established point of view. 